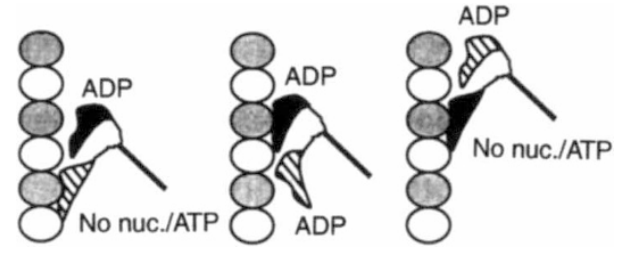

FIG. $4 \mathrm{~A}$ model, based on the observed change in angle, of how a pair of kinesin heads could move $8 \mathrm{~nm}$ along a tubulin protofilament. Although the spikes that project from the heads in our reconstructed images appear short, the extra protein sequence required to form dimers ${ }^{25}$ presumably increases the leverage of the spikes. The simplest way that heads might act alternately over a long distance is for flexible connections to allow them to rotate freely around each other; the direction of movement is determined if, after the attached head changes conformation during ADP release, only the next binding site along the protofilament in the plus direction is within reach of the second head. This model is similar to model A proposed by Hackney ${ }^{15}$, except that the angle change accompanies ADP release instead of ATP binding. The kinesin-like protein ncd moves towards microtubule minus ends. If ncd has a similar projecting spike which is tilted in the opposite direction in the strongly bound no-nucleotide and AMP-PNP states, then motility in the opposite direction could be explained by a similar model.

plus end, and thus produce the 8-nm step (Fig. 4). Therefore our results are consistent with a mechanism in which structural changes in the heads result in directional movement.

Received 11 April; accepted 19 June 1995

1. Hirokawa, N. et al. Cell 56, 867-878 (1989).

2. Scholey, J. M., Heuser, J., Yang, J. T. \& Goldstein, L. S. B. Nature 338, 355-357 (1989).

3. Yang, J. T., Saxton, W. M., Stewart, R. J., Raff, E. C. \& Goldstein, L. S. B. Science 249, 4247 (1990).

4. Romberg, L. \& Vale, R. D. Nature 361, 168-170 (1993).

5. Gilbert, S. P., Webb, M. R., Brune, M. \& Johnson, K. A. Nature 373, 671-676 (1995).

6. Lockhart, A., Crevel, I. \& Cross, R. A. J. molec. Biol. 249, 763-771 (1995).

7. Hirose, K., Fan, J. \& Amos, L. A. J. molec. Biol. (in the press).

8. Song, Y.-H. \& Mandelkow, E. J. Cell Biol, 128, 81-94 (1995).

9. Endow, S. A. Trends biochem. Sci. 16, 221-225 (1991).

10. Goldstein, L. S. B. Trends Cell Biol. 1, 93-98 (1991).

11. Lanzavecchia, S., Bellon, P. L., Dallai, R. \& Afzelius, B. A. J. struct. Biol. 113, 225-237 (1994).

12. Lockhart, A. \& Cross, R. A. EMBO J. 13, 751-757 (1994).

13. Svoboda, K. Schmidt, C. F., Schnapp, B. J. \& Block, S. M. Nature 365, 721-727 (1993).

14. Kuo, S. C. Gelles, J., Steuer, E. \& Sheetz, M. P. in Motor Proteins (J. Cell Science, suppl. 14) (eds Cross, R. A. \& Kendrick-Jones, J.) 135-138 (Company of Biologists, Cambridge, 1991).

15. Hackney, D. D. Proc. natn. Acad. Sci. U.S.A. 91, 6865-6869 (1994).

16. Schnapp, B. J., Crise, B., Sheetz, M. P., Reese, T. S. \& Khan, S. Proc. natn. Acad. Sci. U.S.A. 87, 10053-10057 (1990)

17. Howard, J., Hudspeth, A. J. \& Vale, R. D. Nature 342, 154-158 (1989).

18. Kikkawa, M., Ishikawa, T., Nakata, T., Wakabayashi, T. \& Hirokawa, N. J. Cell Biol. 127, 1965-1971 (1994)

19. Wade, R. H. \& Chrétien, D. J. struct. Biol. 110, 1-27 (1993)

20. Dallai, R. \& Afzelius, B. A. J. struct. Biol. 103, 164-179 (1990).

21. Egelman, E. Ultramicroscopy 19, 367-374 (1986).

22. DeRosier, D. J. \& Moore, P. B. J. molec. Biol. 52, 355-369 (1970).

23. Amos, L. A. \& Klug, A. J. molec. Biol. 99, 51-64 (1975).

24. Vigers, G. P. A., Crowther, R. A. \& Pearse, B. M. F. EMBO J. 5, 529-534 (1986)

25. Huang, T. G., Suhan, J. \& Hackney, D. D. J. biol. Chem. 269, 16502-16507 (1994).

ACKNOWLEDGEMENTS. We thank W. B. Amos for advice and help with Acheta, J. Fan for purified brain tubulin, A. Sperry and S. Brady for the rat kinesin heavy chain clone, M. C. Alonso for construction and purification of N $\Delta 332$. B. Pashley for help with the figures, and R. A. Crowther and R. Henderson for their help and support. K.H. also thanks the Ciba-Geigy Founda tion for financial support during part of this work.
CORRECTIONS

\section{Structure of a new \\ nucleic-acid-binding motif in eukaryotic transcriptional elongation factor TFIIS}

\author{
Xiuqu Qian, ChoonJu Jeon, HoSup Yoon, \\ Kan Agarwal \& Michael A. Weiss
}

Nature 365, 277-279 (1993)

WE previously reported binding of TFIIS residues 231-280 to single-stranded DNA by gel mobility-shift assay (Fig. 1 of this Letter). We have since discovered that the extended form (residues 175-280), rather than the shorter form (residues 231-280), of the protein was inadvertently used in this assay by one of our laboratories (K.A.). The binding of the shorter polypeptide to single-stranded DNA is not reproducible: we therefore retract Fig. 1. Although there is no published spectrofluorometric evidence of interaction between isolated zinc ribbon and nucleic acid, when site-directed mutations in the zinc ribbon domain of the intact protein are used in a stalled transcription assay this domain appears to interact with nucleic acids, as indicated by decrease or elimination of antitermination and RNA cleavage activities'.

1. Jeon, C. J., Yoon, H. S. \& Agarwal, K. Proc. natn. Acad. Sci. U.S.A. 91, 9106-9110 (1994).

\section{Primary production required to sustain global fisheries}

\section{Pauly \& V. Christensen}

Nature 374, 255-257 (1995)

THERE were several numerical errors published in this Letter, some kindly brought to our attention by M. Baumann and T. R. Parsons (personal communication).

- In Fig. 1, the catch of Nile perch should be $0.01 \mathrm{t} \mathrm{km}^{-2} \mathrm{yr}^{-1}$ (not $0.1 \mathrm{t} \mathrm{km}^{-2} \mathrm{yr}^{-1}$ ).

- In Table 1, the primary production required (PPR) for squid in the upwelling system should be 4.1 , that for shrimps on tropical shelves should be 3.5 , and the $k$ value of miscellaneous teleosteans should be 155 .

- In Fig. 2, the abscissa should change in steps of 4\%.

None of these errors affects the results of our study. 